\title{
Northern dry mixed prairie responses to summer wildlife and drought
}

\author{
CATHERINE ERICHSEN-ARYCHUK, EDWARD W. BORK, AND ARTHUR W. BAILEY
}

Authors are former Range Management Specialist, Alberta Agriculture, Food and Rural Development, Hanna, Alberta, Canada, T0J 1P0; and Assistant Professor and Professor emeritus, Department of Agricultural, Food \& Nutritional Science, University of Alberta, Edmonton, Alberta, Canada, T6G 2 P5.

\begin{abstract}
In August 1994, wildfire burned 6,500 ha of native Dry Mixed Prairie in southeastern Alberta. The following year, a study was initiated to monitor the recovery of major plant communities. Burning was followed by 3 successive years of drought, reducing total vegetative cover by $10 \%$. Exposed soil increased to a high of $23 \%$, three years after the fire. Litter and grass production were reduced through 1997, with the greatest decline in 1995 when grass production on burned and unburned areas averaged 890 and $1,468 \mathrm{~kg} \mathrm{ha}^{-1}$, respectively. Of the major forage species, Stipa spp. and Koeleria macrantha (Ledeb. J.A. Schultes f.) were affected for a single year and Agropyron spp. 2 years by burning. Both Agropyron and Stipa abundance displayed interactions with topographic position in response to fire. In 1995, Agropyron increased on uplands with burning from 90 to $143 \mathrm{~kg} \mathrm{ha}^{-1}$, but decreased on lowlands from 383 to $238 \mathrm{~kg} \mathrm{ha}^{-1}$, a pattern repeated in 1996. In contrast, Stipa declined at both positions, but only for a single year. Where livestock grazing occurred after the fire, forage removal was greater on burned areas. Drought conditions, in combination with summer wildfire, reduced Dry Mixed Prairie range productivity and ground cover for several years and intensified livestock grazing, highlighting the need for changes in rangeland management under these conditions.
\end{abstract}

Key Words: composition, forage, litter, preference, production, topography

In August 1994, a late summer wildfire burned through approximately 6,500 ha of native northern Dry Mixed Prairie in southeastern Alberta. Although a number of studies have looked at fire effects in the more mesic northern Mixed Prairie and Fescue Grasslands of the Aspen Parkland in western Canada (e.g. Coupland 1973, Bailey and Anderson 1978, Anderson and Bailey 1980, Redmann et al. 1993, Gerling et al. 1995), relatively little is known of the response of Dry Mixed Prairie vegetation to fire in the Canadian Great Plains. In the single documented study of fire within this region (Clarke et al. 1947), fire was examined during the spring and fall under prescribed conditions rather than as wildfire during the late summer dry period. Wildfires, because they tend to occur during the driest part of the year, are likely to cause greater damage within rangeland ecosystems (Wright 1974b).

Authors wish to thank Lorne Cole, Range Management Specialist for Special Areas District, Hanna, Alberta, for his assistance with data collection, and 2 anonymous reviewers for their comments on earlier versions of the manuscript.

Manuscript accepted 8 Jul. 01.

\section{Resumen}

En Agosto de 1994, un fuego natural quemó 6,,500 ha de Pradera Seca Mixta del sudeste de Alberta. En el año siguiente se inicio un estudio para monitorear la recuperación de las principales comunidades vegetales. La quema fue seguida de tres años consecutivos de sequía reduciendo la cubierta vegetal total en un $10 \%$, y tres años después del fuego, el suelo expuesto se incrementó a un máximo de $23 \%$. El mantillo y la producción de zacates se redujo desde el incendio hasta 1997 , registrándose la mayor disminución en 1995, cuando la producción de zacate de áreas quemadas y no quemadas promedio 890 and 1468 kg.ha ${ }^{-1}$, respectivamente. De las principales especies forrajeras, Stipa spp. y Koeleria macrantha fueron afectadas por la quema solo un año y Agropyron spp. por dos años. La abundancia de Agropyron y Stipa mostraron interacciones con la posición topográfica en respuesta al fuego. En 1995, en las tierras altas, el Agropyron aumento con el fuego de 90 a $143 \mathrm{~kg} . \mathrm{ha}^{-1}$, pero disminuyo en las tierras bajas de 383 a $238 \mathrm{~kg} \mathrm{ha}^{-1}$, este patrón se repitió en 1996. En contraste, el Stipa disminuyó en ambas posiciones, pero solo un año. Cuando el ganado apacento después del fuego la remoción de forraje fue mayor en las áreas quemadas. Las condiciones de sequía, en combinación con los fuegos no prescritos de verano redujeron la productividad de la Pradera Seca Mixta y la cobertura del suelo por varios años, e intensifican el apacentamiento del ganado, resaltando la necesidad de cambios en el manejo de los pastizales bajo estas condiciones.

Rangeland plant communities of the northern Mixed Prairie are generally thought to be well-adapted to wildfire, as this type of disturbance was an important part of these ecosystems prior to European settlement (Bailey 1978). Wright and Bailey (1982) estimate a natural historical fire frequency of 5 to 10 years in the Northern Great Plains. Lightning and aboriginal people were the probable cause of many fires (Nelson and England 1971).

Bailey and Anderson (1978) found that single prescribed burns in spring or fall had little effect on total herbage production in northern Fescue Prairie. In more water-limited environments, rangeland productivity is typically reduced by fire (Redmann 1978, Engle and Bultsma 1984). Fire removes litter, increasing soil temperatures and moisture loss (De Jong and MacDonald 1975, Facelli and Pickett 1991).

Burning can affect the species composition of northern Great Plains rangelands. Burning Fescue Prairie, particularly in fall, reduced Festuca hallii (Vasey) Piper ${ }^{1}$ (Anderson and Bailey 1980, Gerling et al. 1995). Coupland (1973) found Agropyron

\footnotetext{
${ }^{1}$ Nomenclature follows Moss (1992).
} 
smithii Rydb. and Koeleria macrantha (Ledeb.) J.A. Schultes f. declined the year after burning, while Carex spp. and Stipa viridula Trin. increased. Clarke et al. (1947) found Stipa-Bouteloua gracilis (HBK.) Lag. communities to be more tolerant of fire than Agropyron communities in southern Alberta.

Grazing management also influences the recovery of burned rangelands because burning may increase subsequent livestock utilization (Daubenmire 1968, Wright 1974b, Willms et al. 1980). Burned and grazed Mixed Prairie pastures recover more slowly than areas protected from grazing (Clarke et al. 1947). Both Hopkins et al. (1948) and Launchbaugh (1964) found similar results in Shortgrass Prairie.

Although several studies have examined fire impacts on Alberta grasslands, most involve prescribed burning during spring or fall, and have been limited to regions with favorable precipitation. As a result, this study was initiated to examine the effects of the 1994 August wildfire on northern Dry Mixed Prairie ground cover, herbage production and species composition over 3 subsequent years. A second component of the study examined utilization by cattle for 2 years after the fire on adjacent burned and unburned rangeland to assess livestock foraging preferences.

\section{Methods}

\section{Study Area}

The study area is located in the Special Areas administrative district south of Buffalo, Alberta, Canada $\left(50^{\circ} 44^{\prime} \mathrm{N}\right.$, $\left.110^{\circ} 38^{\prime} \mathrm{W}\right)$, within the Dry Mixed Grass Ecoregion (Strong and Leggat 1992). Average summer temperatures for the region are $16.2^{\circ} \mathrm{C}$, and annual precipitation averages $272 \mathrm{~mm}$, with significant moisture deficits during July and August (Strong and Leggat 1992). The landscape of the area is moderately undulating, with soils typically medium-textured, well to moderately well-drained Brown Chernozems (Haploxerolls).

The 1994 wildfire burned over 6,500 ha of Dry Mixed Prairie rangeland, which included an entire grazing lease and approximately $5 \%$ of a local community pasture before being brought under control. Range condition throughout the study area was good to excellent prior to the fire (assessed as per Wroe et al. 1988). Within the community pasture, cattle were free to graze selectively on burned and unburned areas during the course of the study beginning in 1995, at a stocking rate of 0.64 AUM $\cdot$ ha $^{-1}$.
Vegetation within the study area consisted of predominantly cool-season (C3) plants. Available water and soil nutrients severely limit forage production in the region (Strong and Leggat 1992), with plant growth typically complete by midsummer. Dominant plant species include Stipa comata Trin. \& Rupr., Stipa curtiseta (A.S. Hitchc.) Barkworth, Bouteloua gracilis, Agropyron dasystachyum (Hook.) Scribn. and smithii, as well as Koeleria macrantha, with their representation in plant communities heavily dependent on site conditions (Willms and Jefferson 1993). Table 1 shows the relative abundance of major plant species within burned and unburned areas of both upland and lowland topographic positions. Unburned data indicate that the upland and lowland areas are indicative of the Stipa-BoutelouaAgropyron (S-B-A) and Stipa-Agropyron (S-A) faciations, respectively (Coupland 1961). Artemisia frigida Willd. was a common half- shrub throughout the area, with Symphoricarpos occidentalis Hook. present on lowlands as well (Table 1).

\section{Vegetation Sampling and \\ Assessment}

Sample sites were situated within dominant range sites (upland and lowland topography) in May 1995 on the grazing lease. Transects were randomly situated in pairs along the fire-line, on both burned and adjacent unburned areas. Six transects were positioned on lowland sites and 8 on upland sites. Each transect was 20 meters long, randomly positioned and permanently marked.

Table 1. Average species composition (\% weight estimate) of the dominant plant species (minimum $1 \%$ ) at Buffalo, Alberta, within the burned and unburned areas at each topographic position. Data are pooled over all years (1995-1997).

\begin{tabular}{|c|c|c|c|c|}
\hline \multirow[b]{2}{*}{ Species: } & \multicolumn{2}{|c|}{ Upland (S-B-A) } & \multicolumn{2}{|c|}{ Lowland (S-A) } \\
\hline & Burned & $\overline{\text { Unburned }}$ & Burned & Unburned \\
\hline & & $-(\% \mathrm{w}$ & t) & . \\
\hline \multicolumn{5}{|l|}{ Grasses: } \\
\hline Agropyron smithii \& dasystachyum & 11.3 & 7.6 & 13.7 & 15.2 \\
\hline Bouteloua gracilis & 6.2 & 8.4 & 2.1 & 3.2 \\
\hline Carex spp. & 8.5 & 6.3 & 14.0 & 13.4 \\
\hline Koeleria macrantha & 19.8 & 12.8 & 13.2 & 5.6 \\
\hline Poa sandbergii & 7.3 & 2.4 & 3.3 & 1.7 \\
\hline Stipa comata \& spartea var. curtiseta & 37.7 & 39.8 & 50.9 & 52.9 \\
\hline \multicolumn{5}{|l|}{ Forbs: } \\
\hline Anemone patens & 0.4 & 0.2 & 0.7 & 1.3 \\
\hline Artemisia frigida & 1.3 & 17.4 & 0.8 & 3.4 \\
\hline Comandra pallida & 1.0 & 1.0 & 0.2 & 0.4 \\
\hline Sphaeralcea coccinea & 2.2 & 1.6 & 1.2 & 0.9 \\
\hline Vicia americana & 0 & 0 & 0 & 2.1 \\
\hline Zygadenus gramineus & 0 & 0 & 0.6 & 1.4 \\
\hline \multicolumn{5}{|l|}{ Shrubs: } \\
\hline Artemisia cana & 0.9 & 0.3 & 1.0 & 0 \\
\hline Rosa arkansana & 0 & 0 & 1.1 & 0.3 \\
\hline Symphoricarpos occidentalis & 0 & 0 & 6.4 & 6.8 \\
\hline
\end{tabular}

A variation of the weight-estimate technique was used to estimate forage yield. On each transect, six previously unsampled $0.25 \mathrm{~m}^{2}$ quadrats at stratified intervals were assessed in 1995, 1996, and 1997, with lowlands sampled a fourth time in 1998. Yearly vegetation assessments were done at peak standing phytomass (late July to early August), providing a reliable estimate of total forage production (Redmann et al. 1993).

The grazing lease was rested from livestock grazing in 1995 and 1996 to facilitate range recovery. Although pronghorn antelope could not be excluded from the area, forage utilization by this species was estimated to be negligible on the burned area in both years. In 1997 and 1998, $1 \mathrm{~m}^{2}$ cages were used to prevent livestock grazing on all sample quadrats. Cattle use of the area around the transects remained light to moderate, with use never exceeding an estimated $30 \%$.

Data collection on each quadrat was conducted as described in Wroe et al. (1988). For each quadrat, the percent groundcover of total (live and dead) vegetation, bare soil and Selaginella densa Rydb. was estimated using cover classes (Daubenmire 1959). All plant species precontribution of each to total yield, based on dry matter weight, visually estimated. Estimates were later checked by clipping and weighing herbage of each species present within other representative quadrats.

After the cover assessment was complete, all litter and vegetation present in the $0.25 \mathrm{~m}^{2}$ quadrat was harvested. All sent were identified and the percentage 
standing phytomass was clipped at ground level and sorted into dead material, as well as live graminoid, forb and shrub species. Shrubs were combined with forbs due to their limited abundance. Fallen litter was carefully raked from the soil surface and added to standing dead material, with the sum of these components collectively referred to as litter. Lichens, Selaginella densa and Phlox hoodii Richards. were not harvested. Each component was bagged separately by quadrat, dried to constant mass, and weighed, followed by conversion to $\mathrm{kg} \mathrm{ha}^{-1}$ to provide standing crop values. The production of each species per quadrat was determined by multiplying the average proportions estimated for each species by composited dry matter $\left(\mathrm{kg} \mathrm{ha}^{-1}\right)$ harvested by growth form.

On the adjoining Buffalo-Atlee Community Pasture, 4 additional upland sites were randomly selected to assess cattle utilization on burned and unburned Dry Mixed Prairie in 1995 and 1996. Eight cages, each $1 \mathrm{~m}^{2}$, were used to obtain ungrazed herbage production, with 4 cages on each of the burned and unburned areas. At each cage, $0.25 \mathrm{~m}^{2}$ paired quadrats from both inside and outside the cage were assessed using the procedure described previously. Cages were not moved to avoid confounding yield data with localized site heterogeneity; instead, clipped quadrats within cages were rotated to avoid re-sampling in subsequent years. Actual herbage and litter utilization was calculated for each cage as the difference between ungrazed and grazed quadrats.

\section{Analysis}

Statistical analysis was done using Proc GLM in SAS (SAS 1990). All data were evaluated in each of the 3 postfire monitoring years with a $2 \times 2$ factorial model for the effects of burning, topographic position (lowland vs upland) and their interaction (e.g., Burn x Position). Only the Burn and Burn $x$ Position results are presented here as fire was the factor of interest in this study, with any significant interactions used to aid interpretation of the main effect. Dependent variables included the estimated standing crop of major forage species, actual grass, forb, and litter weights, as well as the ground cover of total vegetation, bare soil and Selaginella. All comparisons across the fire boundary occurred within randomly selected but internally uniform range sites. In addition, sample sites were all located where the fire-line was man-made (i.e., grader-bladed), negating the risk of site confoundment across the fire boundary.
Table 2. Seasonal and total precipitation data for the nearest weather station at Brooks, Alberta from 1993 to 1999 , inclusive.

\begin{tabular}{|c|c|c|c|c|c|c|}
\hline \multirow[b]{2}{*}{ Year: } & \multicolumn{4}{|c|}{ Season $^{1}$} & \multirow[t]{2}{*}{ Total } & \multirow[t]{2}{*}{ Deviation $^{2}$} \\
\hline & Winter & Spring & Summer & Fall & & \\
\hline & & & precipita & & & $-(\%)-$ \\
\hline 1993 & 26.5 & 141.2 & 126.2 & 48.5 & 342.4 & 0.4 \\
\hline 1994 & 62.9 & 136.6 & $52.6^{3}$ & 36.6 & 288.7 & -15.4 \\
\hline 1995 & 12.6 & 97.9 & 126.2 & 51.6 & 288.3 & -15.4 \\
\hline 1996 & 12 & 74.2 & 124.6 & 78.6 & 289.4 & -15.1 \\
\hline 1997 & 56.8 & 94.8 & 63.0 & 20.4 & 235.0 & -31.1 \\
\hline 1998 & 77.8 & 143.4 & 63.2 & 28.1 & 312.5 & -8.3 \\
\hline 1999 & 22.8 & 192.9 & 159.8 & 19.7 & 395.2 & 15.9 \\
\hline 7 Year Mean & 36.6 & 138.1 & 99.0 & 41.3 & 315.1 & -7.6 \\
\hline St. Dev. & 23.3 & 47.3 & 36.8 & 17.5 & 48.3 & \\
\hline 30 Year Mean & 47.0 & 131.7 & 113.2 & 49.0 & 340.9 & \\
\hline
\end{tabular}

${ }^{1}$ Winter, spring, summer, and fall, represent the inclusive periods Jan. - March, April - June, July - Sept., and Oct. - Dec., respectively.

${ }_{3}^{2}$ Represents deviation from 30 year mean.

Coincides with time of wildfire.
Cattle utilization data were evaluated only for differences between burn treatments, as all sampling sites were situated on upland topography. For all data sets, each year was analyzed separately in an attempt to assess the specific duration of fire effects. Variables were considered significantly different when $\mathrm{p}<0.05$.

\section{Results and Discussion}

\section{Growing Conditions}

Precipitation in 1994 at Brooks, the nearest weather station approximately 85 $\mathrm{km}$ southwest of the study area, was 289 $\mathrm{mm}, 15 \%$ below the 30 year mean of 341 $\mathrm{mm}$ (Table 2). During the summer of 1994, only $53 \mathrm{~mm}$ of precipitation fell at Brooks: this value is $54 \%$ below the longterm mean and likely provided ideal conditions for the August wildfire. Notably, precipitation for the 15 months leading up to the fire were at or above normal, and may have ensured an adequate supply of fuel through favorable vegetation growth in the summer of 1993 and spring of 1994. Precipitation levels for 4 subsequent years following the fire were indicative of prolonged drought, however, ranging from $31 \%$ below average in 1997 to $8 \%$ below in 1998. (Table 2). Thus, post-fire drought was an influential factor on vegetation recovery.

\section{Ground Cover Response}

Although burned areas were lower in mean total vegetation cover in each of the 3 years after the fire, significant differences $(\mathrm{p}<0.05)$ were limited to 1996 (Table 3). The delayed response may be linked to the extended below-normal levels of precipitation during the post-burn period. Sustained drought would impose an additive stress on plant communities, further affecting their inherent resilience.

The August 1994 wildfire significantly increased bare soil on burned areas for 3 subsequent years (Table 3). Increased bare soil likely reduced available moisture by increasing soil temperatures and surface evaporation, while reducing water infiltra-
Table 3. Effect of burning on mean cover (SE) of key ground components, including Selaginella densa, bare soil, and total live vegetation, within the study area during each of the first 3 years after wildfire.

\begin{tabular}{|c|c|c|c|c|c|}
\hline \multirow[b]{2}{*}{ Variable: } & \multirow[b]{2}{*}{ Year } & \multicolumn{2}{|c|}{ Signif. Tests: } & \multirow[t]{2}{*}{ Burned $^{1}$} & \multirow[t]{2}{*}{ Unburned $^{1}$} \\
\hline & & Burn & Burn x Pos. & & \\
\hline & & $-\ldots$ & lues --------- & --.-- $(\%$ & r) -.....-- \\
\hline \multirow[t]{3}{*}{ Selaginella densa } & 1995 & NS & NS & $26(6)$ & $28(9)$ \\
\hline & 1996 & NS & NS & $30(9)$ & $31(10)$ \\
\hline & 1997 & NS & NS & $53(11)$ & $41(12)$ \\
\hline \multirow[t]{3}{*}{ Bare Soil } & 1995 & $\mathrm{p}<0.01$ & NS & $21(8)$ & $2(0.4)$ \\
\hline & 1996 & $\mathrm{p}<0.01$ & NS & $11(2)$ & $2(0.4)$ \\
\hline & 1997 & $\mathrm{p}<0.01$ & NS & $23(5)$ & $7(3)$ \\
\hline \multirow[t]{3}{*}{ Total Vegetation } & 1995 & NS & NS & $74(6)$ & $84(6)$ \\
\hline & 1996 & $\mathrm{p}<0.05$ & NS & $74(6)$ & $84(6)$ \\
\hline & 1997 & NS & NS & $82(6)$ & $92(3)$ \\
\hline
\end{tabular}

Only main effects are presented as no interactions met the $5 \%$ minimum level of significance. 
Table 4. Effect of burning on mean (SE) grass and forb production, as well as accumulated litter (including standing dead) within the study area, during each of the first 3 years after wildfire. Interaction means are provided only for significant Burn $x$ Position interactions.

\begin{tabular}{|c|c|c|c|c|c|c|c|c|c|}
\hline \multirow[b]{2}{*}{ Variable: } & \multirow[b]{2}{*}{ Year } & \multicolumn{2}{|c|}{ Signif. Tests: } & \multicolumn{3}{|c|}{ Burned } & \multicolumn{3}{|c|}{ Unburned } \\
\hline & & Burn & Burn x Pos. & Upland & Lowland & Total & Upland & Lowland & Total \\
\hline Grass & $\begin{array}{l}1995 \\
1996 \\
1997\end{array}$ & $\begin{array}{c}\mathrm{p}<0.01 \\
\mathrm{NS} \\
\mathrm{p}<0.05\end{array}$ & $\begin{array}{c}\text { NS } \\
\text { NS } \\
\mathrm{p}<0.05\end{array}$ & $\begin{array}{c}810(83) \\
\text { n/a } \\
791(50)\end{array}$ & $\begin{array}{c}1050(55) \\
\mathrm{n} / \mathrm{a} \\
1288(119)\end{array}$ & $\begin{array}{c}890(69) \\
1053(161) \\
1004(113)\end{array}$ & $\begin{array}{c}1120(212) \\
n / a \\
756(70)\end{array}$ & $\begin{array}{c}2166(308) \\
\mathrm{n} / \mathrm{a} \\
1838(225)\end{array}$ & $\begin{array}{l}1468(239) \\
1263(233) \\
1220(238)\end{array}$ \\
\hline Forb & $\begin{array}{l}1995 \\
1996 \\
1997\end{array}$ & $\begin{array}{l}\text { NS } \\
\text { NS } \\
\text { NS }\end{array}$ & $\begin{array}{l}\text { NS } \\
\text { NS } \\
\text { NS }\end{array}$ & $\begin{array}{l}\mathrm{n} / \mathrm{a} \\
\mathrm{n} / \mathrm{a} \\
\mathrm{n} / \mathrm{a}\end{array}$ & $\begin{array}{l}n / a \\
n / a \\
n / a\end{array}$ & $\begin{array}{r}106(33) \\
70(34) \\
85(40)\end{array}$ & $\begin{array}{l}n / a \\
n / a \\
n / a\end{array}$ & $\begin{array}{l}\mathrm{n} / \mathrm{a} \\
\mathrm{n} / \mathrm{a} \\
\mathrm{n} / \mathrm{a}\end{array}$ & $\begin{array}{l}151(29) \\
169(60) \\
180(53\end{array}$ \\
\hline Litter & $\begin{array}{l}1995 \\
1997\end{array}$ & $\begin{array}{l}\mathrm{p}<0.01 \\
\mathrm{p}<0.01\end{array}$ & $\begin{array}{c}\mathrm{p}<0.05 \\
\mathrm{NS}\end{array}$ & $\begin{array}{c}29(29) \\
\mathrm{n} / \mathrm{a}\end{array}$ & $\begin{array}{c}9(9) \\
\mathrm{n} / \mathrm{a}\end{array}$ & $\begin{array}{r}22(19) \\
572(165)\end{array}$ & $\begin{array}{c}400(124) \\
n / a\end{array}$ & $\begin{array}{c}1159(449) \\
\mathrm{n} / \mathrm{a}\end{array}$ & $\begin{array}{c}653(198) \\
1464(452)\end{array}$ \\
\hline
\end{tabular}

tion (De Jong and MacDonald 1975, Facelli and Pickett 1991), thereby amplifying the magnitude of drought effects for 4 years. Defosse and Robberecht (1996) found soil temperatures after burning were 12 to $15^{\circ} \mathrm{C}$ greater due to increased absorption of solar radiation. Burning and loss of litter may also increase plant water stress through reduced snow trapping (Trlica and Schuster 1969, Redmann 1978).

In contrast to soil and vegetation, Selaginella cover was not affected by burning (Table 3), although some of this species was observed to die following the fire. These results contrast those of Dix (1960), who found Selaginella may be killed by fire.

\section{Standing Crop Response}

Graminoid production was reduced by the fire in 1995 and 1997, the first and third growing seasons, respectively (Table 4). Furthermore, the interaction between burning and topographic position was significant in 1997. While uplands recovered by 1997 , grass production on lowlands remained 30\% lower within burned areas, indicating wildfire reduced grass production to a greater extent and for a longer period on these areas. Lowlands were reassessed in 1998 and 4 years after the fire, grass production had recovered and was statistically similar between burned $(1,380$ $\left.\mathrm{kg} \cdot \mathrm{ha}^{-1}, \mathrm{SE} \pm 97\right)$ and unburned $(1,660$ $\left.\mathrm{kg} \cdot \mathrm{ha}^{-1}, \mathrm{SE} \pm 292\right)$ areas $(\mathrm{p}>0.10)$.

These results are consistent with other studies that have found fire reduces grassland herbage production for 1 to 3 growing seasons (Dix 1960, Coupland 1973, Wright 1974a, Redmann 1978, Whisenant and Uresk 1989, Defosse and Robberecht 1996). In the study by Coupland (1973) on mesic Mixed Prairie in Saskatchewan, annual herbage production on burned areas remained 27 to $31 \%$ lower than unburned areas even after 3 years. Spring prescribed burning of Dry Mixed Prairie in southern Alberta reduced forage yield $50 \%$ the first year and $15 \%$ the second year, with full recovery by the third (Clarke et al. 1947).

Much of the production loss may result from the removal of litter. Litter was significantly lower in the burned area throughout the monitoring period, and in 1997 , remained $61 \%$ lower than the unburned area (Table 4). These findings are consistent with White and Currie (1983) and Engle and Bultsma (1984) indicating litter requires considerable time to re-accumulate in semi-arid areas. In western North Dakota, 4 growing seasons were needed for a Stipa comata community to recover after an August fire (Dix 1960). Full litter recovery in more northern temperate grasslands may take even longer (Redmann et al. 1993).

Litter acts as a physical barrier to heat and water flow at the soil surface (Weaver and Rowland 1952), thereby conserving soil moisture via reduced evaporation (Naeth et al. 1991). The physical removal of standing dead and surface litter over 1 to 3 years on northern Dry Mixed Prairie reduces herbage production by 25 to $56 \%$ (Willms et al. 1986, Willms et al. 1993). By removing litter, burning reduces production over an extended period in this semi-arid environment, and may increase the likelihood of yield losses during drought. The significant reduction in grass yield in 1997 may result from the loss of litter coupled with lower spring and summer precipitation that year (Table 2). Given that litter is slow to accumulate within northern Dry Mixed Prairie, management following fire should strive to enhance litter accumulation through measures such as reduced livestock stocking rates.

The variation in vegetation response to fire observed between uplands and lowlands are consistent with those of Clarke et al. (1947) who found Stipa-Bouteloua uplands were more resilient to prescribed burning than moister areas dominated by Agropyron plant communities. Similarly,
Coupland (1973) found a 3 year consecutive decline in annual herbage production of mesic Agropyron range in Saskatchewan after an August wildfire. Generally, lowland vegetation is expected to be more resilient than that on uplands due to a more favorable moisture regime, as lowlands accumulate snow, surface runoff and groundwater. The results found here, however, contrast the notion of enhanced resilience.

There are a number of possible explanations for the landscape-based differences in production between burned and unburned areas. One possibility is that greater fuel loads within lowlands caused greater fire intensities, which in turn led to greater damage to plants, thus offsetting any resilience to wildfire. Another explanation is that drought from 1994 to 1997 may have accentuated subsequent fire impacts by modifying local moisture regimes, further stressing vegetation. The loss of greater quantities of litter from lowlands during the fire may have played a role in further limiting subsequent herbage production. A third possibility is that carbohydrate reserve and/or morphological differences between upland and lowland vegetation resulted in differential tolerances to fire.

Carbohydrate reserves are, among other factors, a function of basic plant phenology, stresses such as fire and defoliation, and the type of plant species (White 1973). In some cases (e.g., big bluestem in Tallgrass Prairie), burning has been found to increase the carbohydrate content of plants (Rains et al. 1975), possibly due to the stimulating effect of mulch removal on regrowth (Ehrenreich 1959). Despite this, little is known about the specific response of carbohydrate levels within cool-season grasses exposed to fire. Species such as Agropyron smithii are considered susceptible to defoliation because of an extended V-shaped carbohydrate cycle (Menke and Trlica 1981), with heavy defoliation capable of reducing carbohydrates (Buwai and Trlica 1977). 
Table 5. Effect of burning on the mean (SE) biomass of Agropyron, Stipa, and Koeleria, the 3 dominant graminoid components within the study area, during each of the first 3 years after wildfire. Interaction means are provided only for significant Burn $x$ Position interactions.

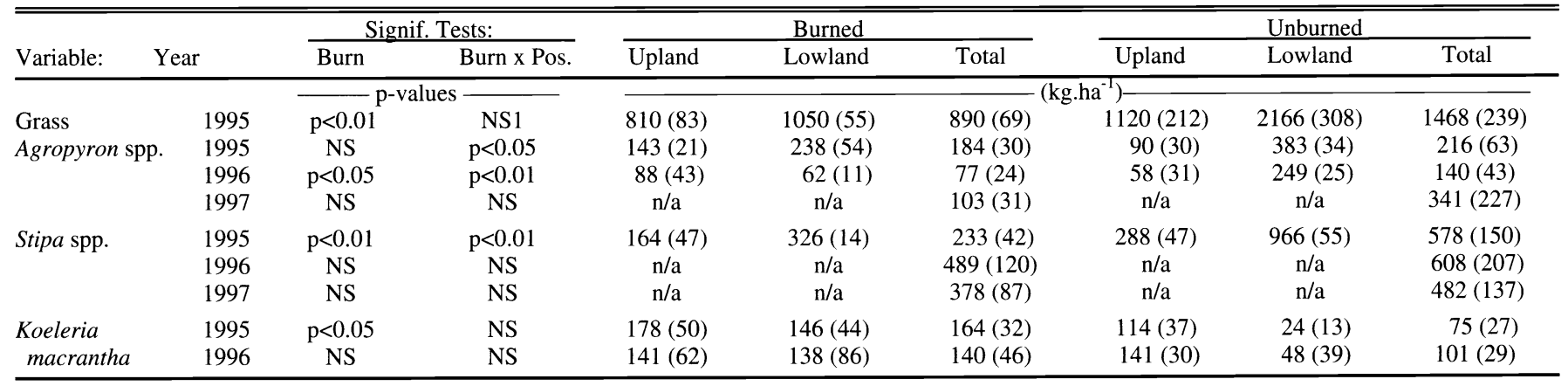

Although the burned area was ungrazed in 1994 following the fire, lowland vegetation may have been more detrimentally affected by an August burn because it was more likely to be actively growing at the time of the fire, as well as more likely to regrow following burning. Throughout the fall of 1994 after the fire, visual estimates of vegetation regrowth were 2 to $4 \mathrm{~cm}$ and 7 to $10 \mathrm{~cm}$ on uplands and lowlands, respectively (Lorne Cole - Special Areas Range Manager, pers. observation). The greater regrowth on lowlands, followed by winter dormancy, would likely deplete both carbohydrate reserves and available lateral buds with minimal opportunity for replenishment, further damaging vegetation at this topographic position and effecting recovery. In contrast, low soil moisture during the summer drought of 1994 would make upland vegetation more likely to remain dormant after fire, minimizing carbohydrate loss and lateral bud death.

In contrast to grasses, wildfire did not significantly reduce peak forb production in any year (Table 4). These results are similar to Redmann et al. (1993) who found burning had little effect on forb phytomass within Mixed Prairie in Saskatchewan. In contrast, Bailey and Anderson (1978) found perennial forb cover in Fescue Prairie increased after burning, as did Engle et al. (1998) on burned mid-successional Tallgrass Prairie. Collectively, these studies suggest that forbs respond favorably to fire, but only in regions where moisture is relatively abundant.

The response of rangeland production to burning partly depends on the timing of fire. Clarke et al. (1947) found fall burning of Stipa rangeland reduced herbage production by $30 \%$ only in the following year, while spring burning resulted in a $50 \%$ decline the first year and a $15 \%$ decrease the second year. The 3 year response documented here on vegetation recovery is evidence of either the intense severity of this wildfire, the impact of drought, or most likely, the interaction between wildfire and subsequent drought. Gerling et al. (1995) observed the same pattern with grass yields in Fescue Prairie, with late spring burning causing the greatest reductions, likely due to a combination of active plant growth coupled with declining soil moisture. These results indicate that although the August 1994 fire may have been detrimental to northern Dry Mixed Prairie rangeland, the impact may have been even more severe had upland plants not completed their annual growth prior to the fire.

\section{Response of Dominant Grasses}

Fire affected the amount of Agropyron spp. in 1995 and 1996 (Table 5), with both years showing a significant interaction between fire and topographic position. Burning reduced Agropyron production on lowlands while increasing it on uplands, producing a response similar to that found by other researchers (Wright 1974b, White and Currie 1983).

Agropyron spp. are normally quite resistant to fire as they have less flammable litter concentrated at the base of the plant near the meristematic tissues, and can regrow from rhizomes (Wright and Bailey 1982). These species may even be favored over others by fall burning (Wright 1974b, White and Currie 1983). The poor response observed at Buffalo, particularly in 1996, may be caused more by moisture stress, as Agropyron spp. frequently decrease during drought (Willms and Jefferson 1993). Although Launchbaugh and Owensby (1978) documented a decline in Agropyron with burning in Kansas, that fire occurred during spring when these species would have been actively growing and thus, more susceptible to fire damage.

Fire also reduced the production of Stipa spp. in 1995 (Table 5), with a significant interaction of fire and topographic position again evident. Burning had a more negative effect within lowlands, but unlike the Agropyron spp., Stipa recovered by the second growing season. The shorter- term decline was unexpected as large bunch grasses have a concentration of dead material at their bases, typically resulting in relatively high temperatures for long periods when burned (Wright 1971). The decline in Stipa observed here is similar to those from other studies indicating fire can harm bunch grasses like Stipa comata (Dix 1960, Wright and Klemmedson 1965, Wright 1971). The timing of fire may also influence the magnitude and extent of Stipa decline. For example, Engle and Bulsma (1984) found Mixed Prairie burned in spring reduced Stipa, but only in the year of the burn, while in southern Idaho, Stipa comata was reduced by burning in June or July, but had more resistance to August fires (Wright and Klemmedson 1965). In contrast, Whisenant and Uresk (1989) found fire in either April or October reduced Stipa comata for up to 3 growing seasons. Based on these studies, it is apparent that even greater decreases in Stipa may have occurred had the wildfire taken place when vegetation was actively growing during spring or fall.

Fire significantly increased Koeleria production in the year following the wildfire (Table 5). The short, tufted habit of this species appears to be more resilient to burning in August than larger bunch grasses. The overall abundance of Poa sandbergii Vasey also appeared to increase after burning (Table 1). Short bunch grasses typically recover quickly after fire (Wright and Klemmedson 1965, Wright and Bailey 1982) as they accumulate less litter and experience lower fire intensities. Although Bouteloua gracilis, a warm season perennial, has been found to decrease following summer burning (Dix 1960, 
Launchbaugh 1964), no notable difference was found in this species between burned and unburned areas (Table 1).

Burning also appeared to reduce the overall abundance of Artemisia frigida (Table 1). Several studies have documented prominent declines in sage with burning, including those by Dix (1960), Coupland (1973), and Bailey and Anderson (1978). The apparent reduction suggests that fire may have the potential for the control of this undesirable species on northern Dry Mixed Prairie rangelands.

\section{Cattle Preference}

Cattle utilized significantly more grass on burned uplands than their unburned counterparts in 1995, but not 1996 (Table 6). Burning typically increases forage preference and utilization (Barker and Erickson 1971, Willms et al. 1980).

Table 6. Evaluation of the Burn $x$ Grazing interaction on year end mean standing crop (SE) on burned and unburned sites within the Atlee Community Pasture grazed during 1995 and 1996, the first 2 growing seasons after wildfire.

\begin{tabular}{|c|c|c|c|c|c|c|c|}
\hline \multirow[b]{2}{*}{ Year } & \multirow[b]{2}{*}{ Variable: } & \multicolumn{2}{|c|}{ Burn x Grazing } & \multicolumn{2}{|c|}{ Burned } & \multicolumn{2}{|c|}{ Unburned } \\
\hline & & F-Value & Probability & Grazed & Ungrazed & Grazed & Ungrazed \\
\hline & & & & 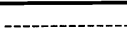 & -1 & $\left.a^{-1}\right)$ & -.----- \\
\hline \multirow[t]{3}{*}{1995} & Grass & 6.72 & $\mathrm{p}<0.05$ & $686(128)$ & $1206(82)$ & $1842(82)$ & $1678(200)$ \\
\hline & Forb & 0.08 & NS & 247 (114) & $229(101)$ & $288(147)$ & $205(98)$ \\
\hline & Litter & 0.04 & NS & $0(0)$ & $0(0)$ & $826(269)$ & $736(356)$ \\
\hline \multirow[t]{3}{*}{1996} & Grass & 2.39 & NS & $910(129)$ & $2080(460)$ & $1400(279)$ & $1670(183)$ \\
\hline & Forb & 0.95 & NS & $220(194)$ & $120(63)$ & $230(106)$ & $600(424)$ \\
\hline & Litter & 0.26 & NS & $340(128)$ & $1070(267)$ & $1880(423)$ & $2080(909)$ \\
\hline
\end{tabular}

Burned areas are preferred because forage is younger, more palatable, and more accessible (Coleman and Barth 1973, Wright 1974b). Post-burn vegetation can be higher in protein and lower in crude fiber (Allen et al. 1976, Willms et al. 1981). Burning also increases utilization simply by removing standing dead litter that acts as a barrier to grazing (Willms et al. 1980).

Grazing inhibits the short-term recovery of desirable forage species and slows the accumulation of litter on burned rangeland, potentially by up to several years (Dix 1960), thereby preventing the stabilization of soils and restoration of normal rangeland hydrologic functions. Many Mixed Prairie species such as Agropyron are strongly affected by defoliation during the growing season (Kowalenko and Romo 1998), and need more than two years rest before attaining full recovery. Given the established preference of cattle for burned areas, the findings of this study lend support to the conclusion of Clarke et al. (1947), that burned and grazed Dry
Mixed Prairie may need 3 to 5 years to recover compared to one to three years for burned pastures that remain ungrazed. As a result, grazing management should be adjusted to account for livestock preferences, with burned areas either grazed separately from unburned areas to facilitate more uniform range use, or unburned areas within a pasture burned off to promote uniform grazing (Launchbaugh and Owensby 1978).

\section{Conclusion}

The August 1994 wildfire in northern Dry Mixed Prairie at Buffalo, Alberta, increased bare soil while reducing grass production and litter for several growing seasons. Rangeland recovery was likely impaired by 3 consecutive years of

Anderson, H.G. and A.W. Bailey. 1980 . Effects of annual burning on grassland in the Aspen Parkland of east-central Alberta. Can. J. Bot. 58:985-996.

Bailey, A.W. 1978. Use of fire to manage grasslands of the Great Plains: Northern Great Plains and adjacent forests. pp. 691693. In: D.N. Hyder (ed.). Proc.of the First Internat. Rangeland Congress. Soc. for Range Manage., Denver, Colo.

Bailey, A.W., and M.L. Anderson. 1978. Prescribed burning of a Festuca-Stipa grassland. J. Range Manage. 31:446-449.

Barker, W.T. and D.O. Erickson. 1971. The effects of burning and mowing on utilization. J. Anim. Sci. 39:985.

Buwai, M. and M.J. Trlica. 1977. Multiple defoliation effects on herbage yield, vigor, and total nonstructural carbohydrates of fire range species. J. Range Manage. 30:164-171.

Clarke, S.E., E.W. Tisdale and N.A. Skoglund. 1947. The effects of climate and grazing practices on short-grass prairie vegetation in southern Alberta and southwestern Saskatchewan. Can. Dep. Agr. Tech. Bull. $46.53 \mathrm{pp}$.

Coleman, S.W. and K.M. Barth. 1973. Quality of diets selected by grazing animals and its relation to quality of available forage and species composition of pastures. $\mathbf{J}$. Anim. Sci. 36:754-761.

Coupland, R.T. 1961. A reconsideration of grassland classification in the Northern Great Plains of North America. J. Ecol. 49:135-167.

Coupland, R.T. 1973. Producers: I. Dynamics of above-ground standing crop. Matador Project. Canadian IBP Prog. Tech. Rep. No. 27. Saskatoon, SK.

Daubenmire, R. 1968. Ecology of fire in grasslands. pp. 209-266. In: Advances in Ecological Research No. 5. Academic Press, New York.

Daubenmire, R.F. 1959. A canopy-coverage method of vegetational analysis. Northw. Sci. 33:43-64.

De Jong, E. and K.B. MacDonald. 1975. The soil moisture regime under native grassland. Geoderma 14:207-221.

Defosse, G.E. and R. Robberecht. 1996. Effects of competition on the postfire recovery of two bunchgrass species. J. Range Manage. 49:137-142.

Dix, R.L. 1960. The effects of burning on the mulch structure and species composition of grasslands in western North Dakota. Ecol. 41:49-56.

Ehrenreich, J.A. 1959. Effect of burning and clipping on growth of native prairie in Iowa. J. Range Manage. 12:133-137.

Engle, D.M. and P.M Bultsma. 1984. Burning of northern mixed prairie during drought. J. Range Manage. 37:398-401.

Allen, L.J., L.H. Harbers, R.R. Schalles, C.E. Owensby and E.F. Smith. 1976. Range burning and fertilizing related to nutritive value of bluestem grass. J. Range Manage. 29:306-308.

Engle, D.M., R.L. Mitchell, and R.L. Stevens. 1998. Late growing-season fire effects in mid-successional tall-grass prairies. J. Range Manage. 51:115-121. 
Facelli, J.M. and S.T.A. Pickett. 1991. Plant litter: Its dynamics and effects on plant community structure. Bot. Rev. 57:1-32.

Gerling, H.S., A.W.Bailey and W.D. Willms. 1995. The effects of burning on Festuca hallii in the parklands of central Alberta. Can. J. Bot. 73:937-942.

Hopkins, H., F.W. Albertson and A. Riegel. 1948. Some effects of burning upon a prairie in west-central Kansas. Kansas Acad. of Sci. Trans. 51:131-141.

Kowalenko, B.L. and J.T. Romo. 1998. Regrowth and rest requirements of northern wheatgrass following defoliation. J. Range Manage. 51:73-78.

Launchbaugh, J.L. 1964. Effects of early spring burning on yields of native vegetation. J. Range Manage. 17:5-6.

Launchbaugh, J.L. and C.E. Owensby. 1978. Kansas rangelands: their management based on a half century of research. Kansas Agr. Exp.. Sta. Bull. 622

Menke, J.W. and M.J. Trlica. 1981. Carbohydrate reserve, phenology, and growth cycles of nine Colorado species. J. Range Manage. 34:269-277.

Moss, E.H. 1992. Flora of Alberta $2^{\text {nd }} E d$ University of Toronto Press, Toronto, Ontario. $687 \mathrm{pp}$.

Naeth, M.A., A.W. Bailey, D.S. Chanasyk and D.J. Pluth. 1991. Water holding capacity of litter and soil organic matter in mixed prairie and fescue grassland ecosystems of Alberta. J. Range Manage. 44:13-17.

Nelson, J.C. and R.E. England. 1971. Some comments on the causes and effects of fire in the northern grasslands area of Canada and the nearby United States, ca. 1750-1900. Can. Geogr. 15:295-306.
Rains, J.R., C.E. Owensby, and K.E. Kemp. 1975. Effects of nitrogen fertilization, burning, and grazing on reserve constituents of big bluestem. J. Range Manage. 28: 358-362.

Redmann, R.E. 1978. Plant and soil water potentials following fire in a northern mixed grassland. J. Range Manage. 31:443-445.

Redmann, R.E., J.T. Romo, and B. Pylypec. 1993. Impacts of burning on primary productivity of Festuca and Stipa-Agropyron grasslands in central Saskatchewan. Amer. Midl. Nat. 130:262-273.

SAS (Statistical Analysis System). 1990. SAS/STAT User's Guide. SAS Institute, Inc., Cary, N.C.

Strong, W.L. and K.R. Leggat. 1992. Ecoregions of Alberta. Alberta Forestry, Lands and Wildlife, Edmonton, Alberta. 59 pp. plus map.

Trlica, M.J. and J.L. Schuster. 1969. Effects of fire on grasses of the Texas high plains. J. Range Manage. 22:329-333.

Weaver, J.E. and N.W. Rowland. 1952. Effects of natural mulch on development, yield, and structure of native grassland. Bot. Gazette 114:1-19.

Whisenant, S.G. and E.W. Uresk. 1989. Burning upland mixed prairie in Badlands National Park. Prairie Nat. 21:221-227.

White, L.M. 1973. Carbohydrate reserves of grasses: a review. J. Range Manage. 26:13-18.

White, R.S. and P.O. Currie. 1983 Prescribed burning in the Northern Great Plains: yield and cover responses of three forage species in the mixed grass prairie. $\mathrm{J}$. Range Manage. 36:179-183.

Willms, W.D. and P.G. Jefferson. 1993. Production characteristics of the mixed prairie: constraints and potential. Can. J. An. Sci. 73:765-778.
Willms, W.D., S.M. McGinn and J.F. Dormaar. 1993. Influence of litter on herbage production in the mixed prairie. $\mathrm{J}$. Range Manage. 46:320-324.

Willms, W.D., S. Smoliak, and A.W. Bailey. 1986. Herbage production following litter removal on Alberta native grasslands. J. Range Manage. 39:536-540.

Willms, W., A.W. Bailey and A. McLean. 1980. Effect of burning or clipping Agropyron spicatum in the autumn on the spring foraging behavior of mule deer and cattle. J. Appl. Ecol. 17:69-84.

Willms, W., A.W. Bailey, A. McLean, and C. Kalnin. 1981. Effects of fall clipping or burning on the distribution of chemical constituents in bluebunch wheatgrass in spring. J. Range Manage. 34:267-269.

Wright, H.A. 1971. Why squirreltail is more tolerant to burning than needle-and-thread. J. Range Manage. 24:277-284.

Wright, H.A. 1974a. Effect of fire on southern mixed prairie grasses. J. Range Manage. 27:417-419.

Wright, H.A. 1974b. Range burning. J. Range Manage. 27:5-11.

Wright, H.A. and A.W. Bailey, 1982. Fire ecology United States and Southern Canada. John Wiley and Sons, Inc. Toronto, ON. 501 $\mathrm{pp}$.

Wright, H.A. and J.O. Klemmedson. 1965. Effects of fire on bunchgrasses of the sagebrush-grass region in southern Idaho. Ecol. 46:680-688.

Wroe, R.A., S. Smoliak, B.W. Adams, W.D. Willms and M.L. Anderson. 1988. Guide to range condition and stocking rates for Alberta grasslands. Alberta Forestry, Lands and Wildlife, Public Lands, Edmonton, AB 